\title{
GUIANA DOLPHINS (Sotalia guianensis) DISPLAYING BEACH HUNTING BEHAVIOR IN THE CANANÉIA ESTUARY, BRAZIL: SOCIAL CONTEXT AND CONSERVATION ISSUES
}

\author{
Marcos César de Oliveira Santos
}

Universidade Estadual Paulista “Júlio de Mesquita Filho" (UNESP)

Projeto Atlantis, Laboratório de Biologia da Conservação de Cetáceos, Departamento de Zoologia (Avenida 24-A, 1.515, Bela Vista, 13506-900 Rio Claro, SP, Brasil)

E-mail: sotalia@gmail.com

\begin{abstract}
To elaborate a fuller description of the beach hunting behavior displayed by Guiana dolphins (Sotalia guianensis) in the Cananéia Estuary (CE) $\left(25^{\circ} \mathrm{S}, 48^{\circ} \mathrm{W}\right)$, a photo-identification study was conducted from May 2000 to July 2003. Three land platforms were chosen at the main entrance of the abovementioned estuary, where scientists enjoy a unique opportunity to observe dolphins at greater proximity, undisturbed. Observations were opportunistic and unevenly distributed in time and space. To enhance the identification efforts, an 80-pound crossbow was used to collect skin samples in order to determine the sex of the eight individuals thus monitored. In 67 days of surveys, rendering approximately $80 \mathrm{~h}$ of direct observations, 4,102 photographs were taken, of which 1,098 $(26.8 \%)$ were considered useful for identification purposes. A total of 103 groups were reported $(3.7 \pm 2.6$ individuals), ranging from solitary dolphins to 15 individuals. Female-calf pairs were observed in $92.4 \%$ of all the groups investigated. On the first occasion, a calving interval was observed for the species in the CE: approximately 3 years and 9 months. Of the 40 individuals identified at least once, eleven used the sloping beaches regularly: females KN \#s 10, 30, 255, 268 and 279; males KN \#s 86 and 257; and four individuals of unknown sex. The characteristics of the associations among beach hunters were evaluated by the analyses of association indices. A total of 83 possible associations between dyads were analyzed using the half-weight index and two selective criteria (5+ and 8+ sightings/individual). Mean association indices varied from 0.12 to 0.16 , evidencing weak bonds among beach hunters. Most regular beach hunters were females, showing that the beach hunting behavior should probably be considered more typically female. Beach hunting in the CE might be considered another example of cultural transmission in cetacean societies.
\end{abstract}

\section{RESUMO}

Com o intuito de detalhar o comportamento de procura e captura de alimento em praias ("beach hunting") exibido por botos-cinza (Sotalia guianensis) no Estuário de Cananéia (EC) $\left(25^{\circ} \mathrm{S}, 48^{\circ} \mathrm{W}\right)$, um estudo baseado na aplicação da técnica de foto-identificação foi conduzido de maio de 2000 a julho de 2003. Três plataformas de observação a foram escolhidas na principal entrada do mencionado estuário, onde os pesquisadores encontram uma oportunidade ímpar de observar os botos a uma pequena distância sem incomodá-los. As observações foram oportunísticas e desigualmente distribuídas ao longo do tempo e do espaço. Adicionadas às observações de identificação individual, uma balestra de 80lbs de pressão foi utilizada para coletar amostras de pele de oito indivíduos monitorados com vistas à determinação do sexo. Em 67 dias de investigação, que renderam aproximadamente $80 \mathrm{~h}$ de observações diretas dos botos, 4.102 fotografias foram tomadas, das quais $1.098(26,8 \%)$ foram consideradas úteis para o propósito de identificação individual. Um total de 103 grupos foi observado $(3,7 \pm 2,6$ indivíduos), variando entre botos solitários e 15 indivíduos. Pares de fêmeas e filhotes foram observados em $92,4 \%$ dos grupos investigados. Apresenta-se a primeira notificação de intervalo de nascimento de um filhote para o EC: aproximadamente 3 anos e 9 meses. De 40 indivíduos identificados ao menos uma vez, onze usaram regularmente as praias: fêmeas $\mathrm{KN}$ \#s 10, 30, 255, 268 e 279; machos KN \#s 86 e 257; e quatro indivíduos de sexo desconhecido. As características das associações entre os indivíduos monitorados foram avaliadas através das análises de índices de associação. Um total de 83 associações possíveis entre pares de botos foi analisado utilizando o índice de peso médio e dois critérios de seleção (5+ e $8+$ avistamentos/indivíduo). A média dos índices de associação variou entre 0,12 e 0,16 evidenciando laços fracos entre os indivíduos monitorados, cuja maioria foi composta por fêmeas, evidenciando-se que o comportamento de uso de águas rasas próxima às plataformas monitoradas para alimentação parece ser direcionado às fêmeas. Este fato evidencia que o comportamento de procura e captura de alimento em praias ("beach hunting") do EC poderia ser considerado como outro exemplo de transmissão de cultura em sociedades de cetáceos.

Descriptors: Cetacea, Sotalia guianensis, Guiana dolphin, Behavior, Beach hunting.

Descritores: Cetacea, Sotalia guianensis, Boto-cinza, Comportamento, Forrageamento. 


\section{INTRODUCTION}

An intriguing plasticity in the foraging and feeding strategies of odontocete cetaceans has been documented in recent decades. The repertoire of capture techniques includes several strategies such as intentional beaching (see HOESE, 1971; LOPEZ; LOPEZ, 1985), when dolphins and killer whales follow their prey onto muddy banks and beaches; fish whacking (see WELLS et al., 1987), when fish are struck out of the water by dolphins' flukes; and sponge carrying (see SMOLKER et al., 1997), when dolphins use sponges on their rostra while exploring reefs (BOWEN et al., 2002). The foraging behavioral displays conducted by cetaceans close to sloping beaches, estuarine mudflats or exposed sandbanks with a view to the capture of their prey has been referred to as beach hunting (see SARGEANT et al., 2005). By definition, beach hunting involves cetaceans surging partially or fully out of the water onto or very close to land platforms to catch single items of prey. The use of sloping beaches and sandbanks for foraging and feeding purposes has been described in detail for several cetacean species such as bottlenose dolphins (Tursiops sp.), killer whales (Orcinus orca), and humpback dolphins (Sousa chinensis) in different coastal and estuarine basins (e.g., HOESE, 1971; LOPEZ; LOPEZ, 1985; GUINET, 1991; PEDDEMORS; THOMPSON, 1994; MANN; SARGEANT, 2003). The social context, as well as motor patterns and prey type, are seen to vary substantially when the beach hunting behavior displayed by different cetacean populations is compared (SARGEANT et al., 2005).

The first observations on Guiana dolphins, Sotalia guianensis (Van Benédèn 1864), displaying foraging behaviors close to sloping beaches were reported in the Cananéia Estuary $(\mathrm{CE})\left(25^{\circ} \mathrm{S}, 48^{\circ} \mathrm{W}\right)$, southeastern Brazil (MONTEIRO-FILHO, 1995). Later, further details were described by SANTOS et al. (2000) after monitoring individually recognized dolphins engaged in beach approaches to capture prey. Although Guiana dolphins do not actually strand themselves on the beach to catch prey, they usually catch fish very close to the exposed sand and regularly remain several hours investing in approaches to land platforms (see SANTOS, 2004). Moreover, usually several individuals patrol the same small sections of the estuary, sometimes remaining less than $1 \mathrm{~m}$ from the shoreline. For this reason $S$. guianensis may also be included in the list of cetaceans known to display beach hunting foraging strategies. To elaborate a fuller description of the beach hunting behavior displayed by $S$. guianensis in the CE, a longitudinal photoidentification study has been being conducted since 1996 from land-based platforms (see SANTOS et al., 2001). As of July 2003, land and boat-based efforts produced a photographic database containing 147 individuals (SANTOS; ROSSO, 2008). Most of the dolphins identified are resident in the CE, since they have been photographed in successive seasons and years (SANTOS et al., 2001; SANTOS; ROSSO, 2008). Based on the scenario described, the characteristics of the associations among Guiana dolphins when displaying their beach hunting behavior in the CE have been evaluated in order better to understand the social context of the beach hunters. Descriptions of two main examples of foraging behavior are also presented, as well as the first notification of the kerplunking behavior displayed by S. guianensis.

\section{Material and Methods}

\section{Study Area}

The CE is situated on the southern limit of São Paulo state ( $\left.25^{\circ} 01^{\prime} \mathrm{S}, 47^{\circ} 55^{\prime} \mathrm{W}\right)$, Brazil, and is part of a $180 \mathrm{~km}$ long estuarine system extending from Iguape to Paranaguá (Fig. 1A). The estuary has a muddy bed and relatively turbid, shallow waters (SCHAEFFER-NOVELLI et al., 1990). It is surrounded by extensive mangrove forests and is connected to coastal waters through six openings. This study was conducted at the main entrance of the $\mathrm{CE}$ from the following land platforms: "Pereirinha" or "Itacuruçá" beach, "Praia da Barra" and "Ponta da Trincheira" (Fig. 1B). These platforms provide a unique opportunity to observe Guiana dolphins at closer proximity, undisturbed. "Pereirinha" is approximately $3 \mathrm{~km}$ in length and located at the northernmost extremity of Ilha do Cardoso, a natural reserve established as a state park in 1962. "Praia da Barra", also $3 \mathrm{~km}$ long, is located on the southernmost point of Ilha Comprida, an island-county with a length of $74 \mathrm{~km}$. "Praia da Barra" is connected to inner estuarine waters through a $1 \mathrm{~km}$ long inlet known as "Ponta da Trincheira", also situated on Ilha Comprida.

\section{Photo-Identification}

The data presented in this study are derived from efforts at photo-identification undertaken from May 2000 to July 2003. The observations were made from the above-mentioned platforms, were opportunistic and unevenly distributed in time and space, and were all made during the daylight hours. Individuals were identified by the shape of their dorsal fin and marks found on that fin using the photoidentification technique (WÜRSIG; WÜRSIG, 1977), in accordance with the recommendations made by WÜRSIG; JEFFERSON (1990). A $35 \mathrm{~mm}$ reflex camera, with a $300 \mathrm{~mm}$ zoom lens and ISO 400 color films, was used. Photographs of the dolphins studied were taken at distances ranging from one to eight meters. Photographs were taken with shutter speeds 
ranging between $1 / 500 \mathrm{~s}$ and $1 / 2000 \mathrm{~s}$ and were analyzed with the help of 10x eyecup lenses. Details of the criteria used to evaluate the quality of photographs are those described in SANTOS; ROSSO (2008). Whenever possible, the prey items captured by $S$. guianensis were identified from photographs.

\section{Definitions}

A group of Guiana dolphins was defined as any aggregation of two or more individuals, including female-calf pairs, observed in close proximity to each other, i.e., within a radius of approximately $10 \mathrm{~m}(10$ $m$ chain rule sensu SMOLKER et al., 1992). These aggregations were generally, though not necessarily, engaged in similar activities. Group size and the proportion of adults/juveniles and calves were reported every five minutes. Only two age classes could be described precisely: (1) calves, individuals whose body length was $1 / 2$ or less that of other individuals in the area and usually remained close to their mothers, and (2) juvenile/adults, including any other dolphins observed. Occasionally, more than one group of dolphins were seen on the same survey date. Behavioral activities were grouped in four different categories: feeding, traveling, socializing and resting (sensu SHANE, 1990). Data on these activities were collected every five minutes.
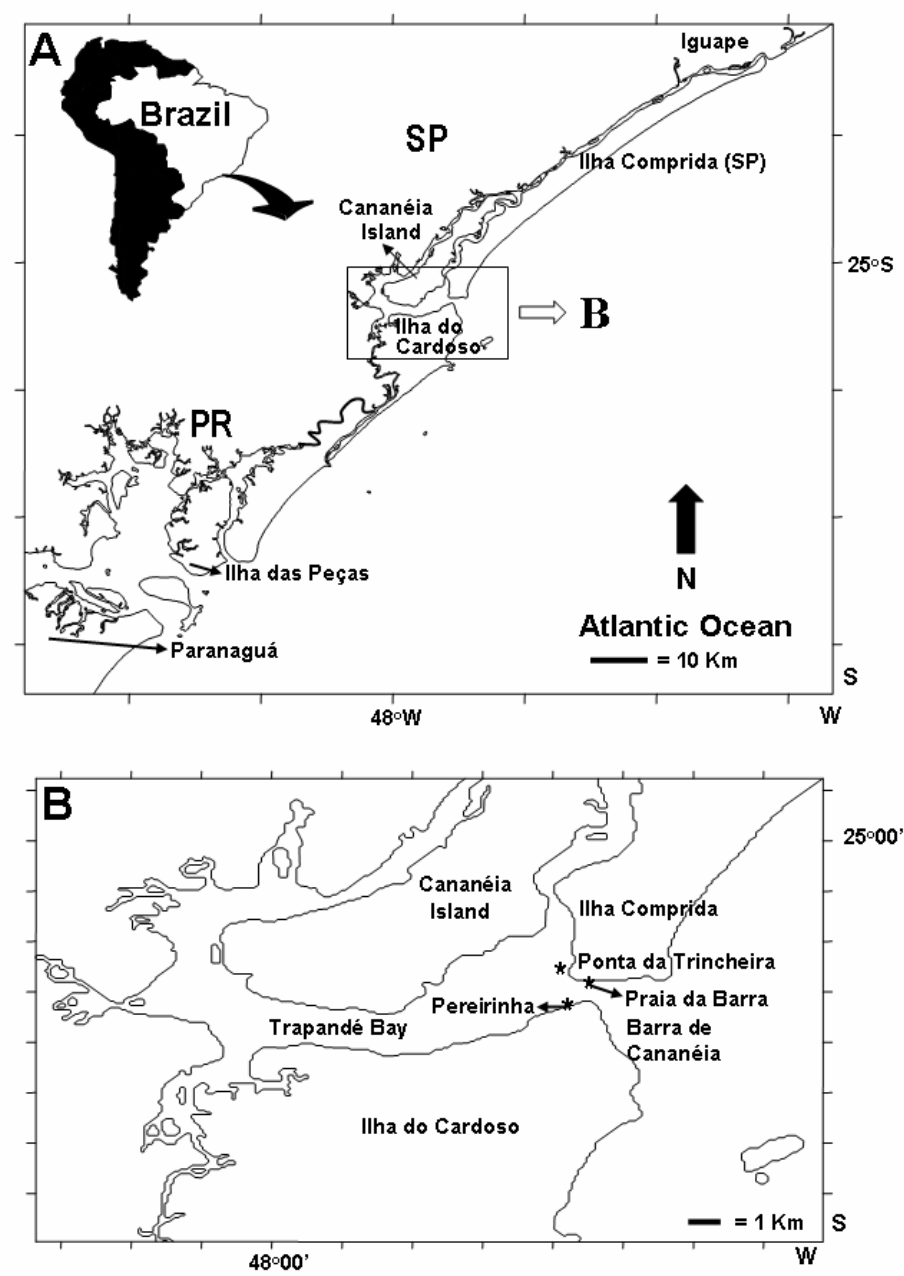

Fig. 1. Map showing the southern portion of São Paulo state and the northern portion of Paraná state (A), Brazil, where Guiana dolphins (Sotalia guianensis) can be found year round in estuarine waters. The land-based platforms where observations took place are shown in detail (*). 
A beach hunting behavioral display was defined as any frequent fast swim conducted by one or more dolphins in shallow waters (less than $3 \mathrm{~m}$ in depth), followed by the chasing of an individual or school of fish for several meters parallel to and close to the beach surface. Thus, the term beach hunter refers to all individuals engaged in such behavioral displays.

\section{Determination of Sex}

Several individuals were classified as females after long-term observation in close companionship with calves. An 80-pound crossbow was used to collect skin samples of eight individuals between October 2002 and July 2003. DNA was extracted from these tissues in accordance with the method described by BRUFORD et al. (1992) and the sex was determined by PCR and electrophoresis in $1.5 \%$ agarose gel following the procedures described by BÉRUBÉ; PALSBOLL (1996).

\section{Association Analysis}

The half-weight index (CAIRNS; SCHWAGER, 1987; GINSBERG; YOUNG, 1992) was used for the investigation on the social context involving beach hunters (see WHITEHEAD, 1997; WHITEHEAD; DUFAULT, 1999). All dolphins photographed in the same group were recorded as "in association". In order to avoid bias, female-calf pairs were excluded from this investigation and only groups photographed complete were included in the analyses. A selective criteria involving more than one class of individual sighting occasion was adopted (see CHILVERS; CORKERON, 2002). The investigation therefore included individual dolphins with $5+(n=$ $11)$ and $8+(n=8)$ distinct sightings. These criteria were used to balance the maximum number of individuals to ensure representative data, as well as the maximum sighting frequencies to ensure reliability of data (BEJDER et al., 1998; WHITEHEAD, 1999). To minimize auto-correlation of collected data and to ensure the independence of sampling procedures, groups composed of individuals previously identified on the same day were excluded from the analyses $(n=4)$. Analyses were performed using SOCPROG 1.3 software (WHITEHEAD 1995; 1999), run in MATLAB $^{\circledR} 5.3$ (The Math Works, Inc., Natick., Mass., EUA, 1999). The gathered association values were classified based on the categories proposed by QUINTANA-RIZZO; WELLS (2001). To test the null hypothesis that there were no preferred or avoided companions given the number of groups in which each animal was seen during the sampling period, the Monte Carlo method (MANLY, 1997) was used, in accordance with the recommendations presented by BEJDER et al. (1998) and WHITEHEAD (1999). To test for both long and short term preferred associations in all investigations, this test was run five times, fixing 20,000 permutations on the original matrix.

\section{RESULTS}

A total of 67 distinct days were dedicated to land-based surveys, rendering $80 \mathrm{~h}$ of direct observations. Dolphins were observed displaying feeding and foraging activities on most occasions (79.1\% of direct observations), and rarely observed using local beaches for socializing purposes $(0.1 \%)$. Resting was the second behavioral category recorded $(9.5 \%)$ and was usually observed in the intervals between foraging and feeding activities close to the shore. In $3.2 \%$ of all observations, dolphins passed close to local beaches without stopping or conducting any other behavioral activities. On some occasions it was not possible to ascertain what behavioral activities the dolphins were engaging in $(8.1 \%$ of direct observations).

A total of 103 groups were reported to have used local shallow waters: mean $\pm \mathrm{SD}=3.7 \pm 2.6$ individuals, ranging from solitary dolphins to 15 individuals. Of the total number of groups reported, a total of 70 were observed from "Ponta da Trincheira" and "Praia da Barra" and 33 others from "Itacuruçá". Of the 365 individuals observed, including repetitive counting on the same and on distinct dates, 265 $(72.6 \%)$ were adults/juveniles and $100(27.4 \%)$ were calves. Female-calf pairs were observed in $92.4 \%$ of all the groups investigated performing beach hunting close to local platforms.

Of 4,102 photographs, 1,098 (26.8\%) were considered useful for identification purposes. Forty identified individuals were observed at least once close to land platforms. Female KN \#10 presented the highest number of sightings $(n=43)$. Five adults were identified as females based on their close association with calves: KN \#s 10, 30, 255, 260, and 268. Skin samples were collected from four adult females (KN \#s 10, 255, 260 and 279) and from two adult males (KN \#s 86 and 257). Two calves were also biopsied: a male calf of $\mathrm{KN} \# 255$, which disappeared during a summer season four to five months after it had first been observed as a newborn, and a female calf of $\mathrm{KN}$ \#10, nicknamed "Crooked Fin". This latter calf was born with a fin bent to the left and usually whistled after breathing, giving observers a rare opportunity to follow a "marked" Guiana dolphin calf in the wild. Born sometime in February or March of 2000, "Crooked Fin" was still alive and using local waters as of January 2010. In November 2003, KN \#10 had another offspring, providing researchers with the first notification of a calving interval for Guiana dolphins in Cananéia estuarine waters: approximately three years and nine months. This offspring disappeared in a summer season 14 months after it had initially been 
sighted. In those 14 months, "Crooked Fin" was sighted with the female-calf pair, as well as alone or in the companionship of other beach hunters when they were using sloping beaches. None of the other females quoted had calves that could be tracked because they had no distinct notches.

Two main foraging strategies were reported in this survey. The "waiting" strategy was adopted when individual dolphins approached shallow waters in order to wait for a school of fish. They remained in the same place, at $c a .1 \mathrm{~m}$ from land, for up to $10 \mathrm{sec}$ with their caudal fin usually lying close to the bottom, making up and down movements with their bodies always showing their dorsal fin and blowhole, and suddenly moving towards any school of fish which crossed close to the shore. In another foraging strategy, named "beach attack", one or more dolphins herded a school of fish from deeper to shallower waters and suddenly tried to "corner" the fish very close to the shore. Although the "waiting" tactic usually ended with an attack towards the beach, it was clear that both strategies were initially completely different. All beach hunters and their calves were observed displaying beach attacks, but only six individuals (KN \#s 10, 86, 255, 268, 279 and "Crooked Fin") were reported displaying the "waiting" strategy. Two individuals (KN \#86 and "Crooked Fin") displayed kerplunking behavior (sensu CONNOR et al., 2000). When performing the kerplunking behavior, dolphins usually flap their flukes on the water surface in order to scare bottom dwelling fish, thus making their pursuit easier. No other individuals were seen displaying this foraging behavior in the period surveyed.

Photographed prey items included two different species of mullet (Mugil platanus, known as "tainha" and Mugil curema, known as "parati"), the rake stardrum (Stellifer sp., known as "xingó"), and the halfbeak or ballyhoo (Hemiramphus brasiliensis, known as "agulhinha").

Eleven dolphins regularly used (5+ occasions) sloping beaches: females KN \#s 10, 30, 255, 268, and 279; males KN \#s 86 and 257; and four individuals of unknown sex $\mathrm{KN} \# \mathrm{~s} 43,71,83$, and 271. The results of the association analyses based on two different selective criteria are shown in Table 1. From eight to eleven individuals were included in these analyses, depending on the selective criteria. A total of 83 possible associations between dyads were analyzed using the half-weight index and two selective criteria (5+ and 8+ sightings). Mean association indices varied from 0.12 to 0.16 , giving evidence of weak bonds among beach hunters (see Figs 2 and 3). The observed association indices were grouped in the low category in accordance with QUINTANARIZZO; WELLS (2001). No dyads were observed in the short or long-term preferences.

Table 1. Summarized data from the analyses of associations among Guiana dolphins (Sotalia guianensis) displaying beach hunting behavior in the Cananéia estuary, Brazil, from May 2000 to July 2003. Mean and standard deviation (SD) of the association indices observed in the real and in the randomized communities from the original matrices are shown. HWI means half-weight index.

\begin{tabular}{cccccc}
\hline \hline & & Observed & Randomized Data & \\
\hline $\begin{array}{c}\text { Selection } \\
\text { criteria }\end{array}$ & $\begin{array}{c}\text { \# Ids in } \\
\text { analysis }\end{array}$ & $\begin{array}{c}\text { Percentage of zero } \\
\text { associations }\end{array}$ & $\begin{array}{c}\text { HWI } \\
\text { Mean } \pm \text { SD }\end{array}$ & $\begin{array}{c}\text { HWI } \\
\text { Mean } \pm \text { SD }\end{array}$ & $p$ \\
\hline $\mathrm{N} \geq 5$ & 11 & 29 & $0.122 \pm 0.138$ & $0.121 \pm 0.136$ & 0.64 \\
$\mathrm{~N} \geq 8$ & 8 & 38 & $0.159 \pm 0.150$ & $0.158 \pm 0.135$ & 0.67 \\
\hline
\end{tabular}

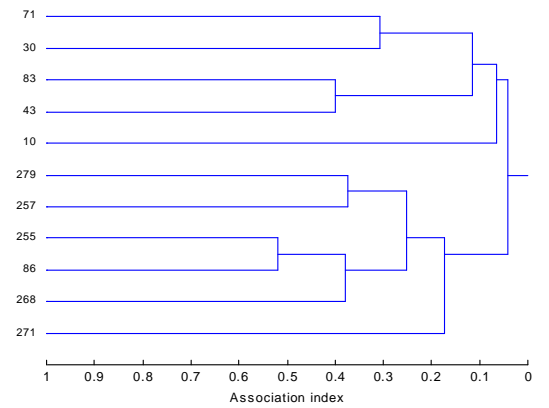

Fig. 2. Cluster diagram showing the associations among Guiana dolphins (Sotalia guianensis) with 5+ sightings ( $n=11$ individuals) when displaying beach hunting behavior in the Cananéia estuary, Brazil, from May 2000 to July 2003.

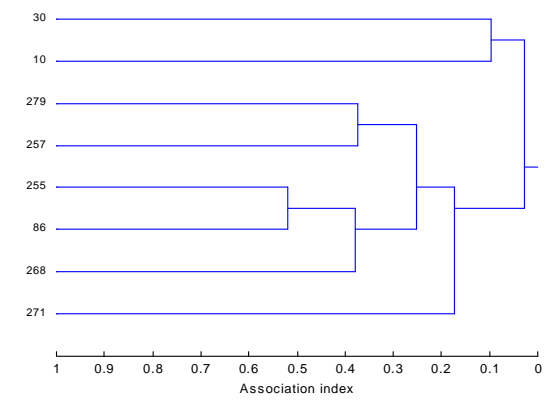

Fig. 3. Cluster diagram showing the associations among Guiana dolphins (Sotalia guianensis) with 8+ sightings ( $n=8$ individuals) when displaying beach hunting behavior in the Cananéia estuary, Brazil, from May 2000 to July 2003. 


\section{DisCUSSION}

The murky waters commonly found in the CE limited the investigation of further aspects of the beach hunting behavior displayed by Guiana dolphins. For instance, it was not always possible to evaluate whether a foraging bout was successful. However, even with such limitations it was possible to gather baseline information on $S$. guianensis beach hunters, such as the characteristics of group size and composition when using shallow waters, the determination of one calving interval, the description of two distinct foraging tactics, the first report of the kerplunking behavior displayed by $S$. guianensis, and the observation of weak bonds among beach users. Moreover, it was possible to identify prey species by the analyses of photographs showing captured items in the mouths of several individuals.

When observed from land platforms, Guiana dolphins usually displayed foraging and feeding activities or patrolled local platforms for food. Schools of fish can be found close to the sites quoted as a strategy to avoid the larger predators commonly found in deeper waters. At least two different mullet species (Mugilidae) can be found in larger aggregations in the $\mathrm{CE}$, usually in the water column or foraging on the bottom (MENDONÇA; KATSURAGAWA, 1997; MACIEL, 2001). Also, bottom-dwelling Sciaenid fish species are abundant year-round (MACIEL, 2001). SANTOS et al. (2002) showed that most fish species described as $S$. guianensis prey items in the local estuary emit sound through their swim bladder, providing clues as to their location in a dark water environment. As a consequence, Guiana dolphins may have developed different strategies (e.g. beach hunting, kerplunking) in order to take advantage of the available prey.

The beach hunting displayed by Guiana dolphins in the CE has some similarities with as well as differences from the foraging strategies of the bottlenose dolphins described by MANN; SARGEANT (2003) and SARGEANT et al. (2005) in Shark Bay, Western Australia. One of the similarities is related to the choice of prey species. Both bottlenose and Guiana dolphins are known to catch mullet when engaging in beach hunting behavioral displays. Guiana dolphins, just as the bottlenose dolphins in Australia, were observed conducting belly-up chases. Once the chase has ended, $S$. guianensis also customarily returns to deeper waters (>3 m) by means of a " $\mathrm{u}$ turn" and remains there for several minutes before returning for another bout. Two or more individuals have also been observed engaging in beach hunting displays simultaneously in close proximity to each other. One of the main differences between the sites quoted was that the attacks in the CE occurred almost daily with multiple bouts occurring per day, while in
Shark Bay bouts did not take place on such a regular basis. Guiana dolphins are known to conduct cooperative and coordinated chases to "corner" schools of fish in shallow waters. These chases may involve from two to nine individuals. On the other hand, beach hunters in Australia usually engaged in individual bouts. Finally, no intentional stranding has been recorded for Guiana dolphins in the $\mathrm{CE}$ as has been described for bottlenose dolphins in Shark Bay and at other sites (see HOESE, 1971; PEDDEMORS; THOMPSON, 1994; SARGEANT et al., 2005), as well as for killer whales in Argentina and on the Crozet Islands (see LOPEZ; LOPEZ, 1985; GUINET, 1991).

Only two beach hunters were observed using kerplunking: male \#86 and female "Crooked Fin". The most intriguing question relates to understanding how both learned to forage in this way. $\mathrm{KN} \# 10$, the mother of "Crooked Fin", was never seen to use kerplunking, and $\mathrm{KN} \# 86$ is a male which might be supposed to learn such behavior from its mother. MANN; SARGEANT (2003) presented at least five different cases of calves engaging in a foraging type of behavior not seen in their mothers in Shark Bay, which may also be the case regarding those two Guiana dolphins. A longer term study may provide clues to a better understanding of how types of foraging behavior are learned among beach hunters.

On only one occasion have 15 individuals been observed on a beach patrol engaged in foraging and feeding activities for almost 40 minutes, and a few groups composed of from 6 to 11 individuals have been observed from land engaged in socializing activities at a distance from the beach (10 to $15 \mathrm{~m})$. The mean group size observed from all the sites was 3.7 individuals, which was significantly smaller than that of groups observed from boats throughout the estuary (see SANTOS; ROSSO, 2007). One intriguing question still to be answered is: what are the main factors that limit the use of such sites by larger groups for feeding purposes? These factors are likely to be related to the location of these sites, their relatively short length posing a limitation on their carrying capacity, and the energy invested in learning the skills necessary to be a beach hunter. The sites are located close to open waters and are sometimes subject to stronger waves which could put beach hunters at greater risk of stranding. A total of three individuals were found dead on the platforms between 1995 and 1998 (SANTOS et al., 2002). On one occasion in 2002, one adult dolphin remained stranded for almost one minute after performing a bout at "Ponta da Trincheira", but left afterwards moving its body up and down. If a higher number of dolphins were to concentrate close to the shore for longer periods, there would be an increasing probability that fewer prey items would find shelter in a location full of predators. 
Seen from this point of view, another factor that may be involved in the social context related to beach hunters is the possibility of intraspecific competition. As a consequence, beach hunters would somehow control the use of such sites. Although a few groups were seen engaged in socializing activities close to the shore, it was not possible to ascertain whether the physical contacts observed were of an aggressive nature. Bioacoustic studies, together with underwater video recordings using appropriate equipment adapted for murky waters, may highlight possible clues to intraspecific competition. It is also important to bear in mind the aspects suggested by Mann; Sargeant (2003) and Sargeant et al. (2005) regarding the cost of the skills involved in social learning. However, to engage in a broader discussion of this aspect, researchers will need to accompany the next generations of Cananéia beach hunters in a longer-term study.

The analyses of associations among beach hunters showed that there is a lack of consistency among group members. These findings are similar to those described in other small cetacean social organization studies (e.g. WELLS et al., 1987; WELLS, 1991; CONNOR et al., 1992; SMOLKER et al., 1992; SLOOTEN et al., 1993; KARCZMARSKI, 1999; QUINTANA-RIZZO; WELLS, 2001; CHILVERS; CORKERON, 2002; OWEN et al., 2002), as well as to the analysis of the databases collected from boat-based surveys throughout $\mathrm{ca}$. $124 \mathrm{~km}^{2}$ of the CE carried out in the same period as the land-based survey (SANTOS; ROSSO, 2008). Beach hunting groups of Guiana dolphins temporarily merged into casual and short-lasting associations, but eventually split up. Although one would expect beach hunters to be highly associated with the same congeners, the Monte Carlo method showed that beach hunters associated randomly, without there being any preferred dyads.

Foraging behavior such as beach hunting displays presents an avenue for investigating social learning traditions among cetaceans (MANN; SARGEANT, 2003). In recent years, many authors have been discussing the relevance of cultural transmission in cetaceans (e.g. MANN, 2001; RENDELL; WHITEHEAD, 2001; WHITEHEAD et al., 2004; KRÜTZEN et al., 2005; SARGEANT et al., 2005). In a longitudinal study of bottlenose dolphins in Australia, it has been shown that foraging traditions are more likely transmitted to daughters than to sons (KRÜTZEN et al., 2005). It seems that beach hunting should probably be considered a female-biased form of behavior among Guiana dolphins in CE. Most of all the regular beach hunters were females. With the exception of $\mathrm{KN} \# 86$, the "waiting" foraging strategy was displayed by females only. As of July 2008, only one female ("Crooked Fin") has been seen continuously engaged in beach hunting behavior. All the other offspring disappeared soon after their birth, either dying or maybe joining the general population without being cataloged or identified by sex. Calves start displaying bouts in their first year of age usually close to, or with, their mothers. After at least one year, they start displaying independent bouts at a distance from their mothers. Baby-sitting when more than one adult female is performing beach hunting has previously been described by Santos et al. (2000). One adult female used to remain in deeper waters in the company of two calves, while the other one was engaged in the beach hunting. In this study, babysitting was commonly observed when KN \#10, its "third" reported calf and "Crooked Fin" were chasing fish close to sloping beaches. The use of shallow waters may provide advantages for females with calves, such as a decrease in the amount of energy invested in food consumption while monitoring their young in the surrounding area. Males' historical data are different from those of females. KN \#86 has received fish handouts for at least 15 years close to local artisanal traps known as "cercos" at "Ponta da Trincheira" (see SANTOS et al., 2000). Male KN \#257 remained constantly close to "Ponta da Trincheira" up to 2001, and then began to show up only after longer intervals ( 3 to 9 months), remaining for just a few weeks close to one of the platforms. No further sightings of this individual have been reported in inner waters (see SANTOS, 2004).

"Pereirinha" has been receiving the largest number of tourists, as it is the main gateway for visitors to the Ilha do Cardoso state park. It also offers the public the rare opportunity to watch Guiana dolphins at such close proximity that it has been attracting an increasing number of tourists every year. "Ponta da Trincheira" is on the main route from Cananéia to coastal waters for fishing and the use of recreational speed boats. There is just one narrow channel near that site on which boats may navigate safely without the danger of colliding with sand banks. A female beach hunter has seven parallel, healed wounds along the right side of its body (Fig. 4). They must have been caused by a boat propeller, probably when the dolphin was engaged in foraging close to a sloping beach. Boat traffic means noise pollution, which may disrupt dolphins' communication. Feeding beach hunters also constitutes another threat to their

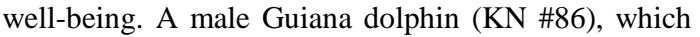
is also a beach hunter, has been fed for at least 15 years (see SANTOS et al., 2000). Various experiences in feeding wild dolphins have been proved to be harmful both to them and to humans (e.g. BRYANT, 1994; IFAW et al., 1995; CONSTANTINE, 1999; MANN; KEMPS, 2003). Changes in dolphins' natural behavior, for example, in their foraging for food and the breaking of social bonds; a loss of wariness of humans that places the animals at risk; the ingestion of 
inappropriate or contaminated food; and an increase in the number of reported injuries to humans are the main problems cited in various studies. However, handfeeding is still practiced by three local fishermen who own two fishing traps at the "Ponta da Trincheira". They have been doing this when receiving field trips. No other Guiana dolphin has so far been observed being hand-fed. In Australia, all calves that engaged in boat-begging had mothers who had been fed and boat begging on the part of mothers and calves was significantly associated (MANN; SEARGEANT, 2003). These factors represent disadvantages involved in the use of such restricted areas by beach hunters.

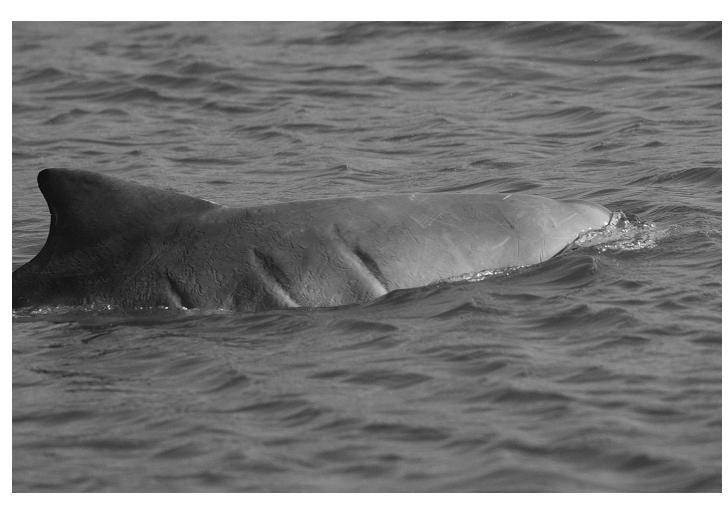

Fig. 4. Female Guiana dolphin (Sotalia guianensis) commonly found in foraging and feeding activities in the Cananéia estuary, showing seven propeller marks on the right side of its body. Photo: Marcos Santos.

Based on the concerns quoted, a new regulation for boaters was implanted by the state park staff in 2007 in order to organize the use of "Pereirinha" beach by tourists in such a manner as to minimize their impact on local dolphins. A buffer zone was established for bathers and dolphins where boats are not allowed. The same steps should be taken for both land platforms on Ilha Comprida. WHITEHEAD et al. (2004) suggested that in some circumstances and for some species, culture should be integrated into conservation biology. These authors based their suggestion on the definition of culture proposed by RENDELL; WHITEHEAD (2001): "information or behavior - shared by a population or subpopulation which is acquired from conspecifics through some form of social learning". Based on: (1) the suggestion posed by WHITEHEAD et al. (2005), (2) the rare types of foraging behavior described for $S$. guianensis in the CE, probably another evidence of cultural transmission in cetacean societies, (3) the long period of dependence of Guiana dolphin calves (at least 3 years and nine months, as shown for "Crooked Fin") and (4) the threats described above posed to the few beach hunters in the population, it is recommended that more specific actions should be taken to preserve such a rare phenomenon. The first step was taken in 2007 with the publication of the first regulation to protect the beach hunters which used "Pereirinha". This decision will at least give time for researchers to conduct a more detailed longitudinal study so that the way this tradition has been passed down through generations of $S$. guianensis beach hunters may be better understood.

\section{ACKNOWLEDGEMENTS}

We wish to thank The Whale and Dolphin Conservation Society, the International Cetacean Society and Fundação de Amparo à Pesquisa do Estado de São Paulo (FAPESP; process number 01/05128-8) which gave financial support for the photo-identification studies of Guiana dolphins in the Cananéia estuary. We are grateful to the Instituto Oceanográfico da Universidade de São Paulo for their support in the field as also to the following researchers for their help in the field campaigns: B. Kafejian, L. Acuña, D. Pivari, A. Azevedo, P. Del Nero, E. Favaro, E. da Silva and 61 fellows from Programa de Estágio - Projeto Atlantis. Biopsy sampling was conducted under IBAMA permits \#s 02/01-CMA and 012/03-CMA (process 02001.006352/00-31). Tissue and extracted DNA were stored and analyzed by Tânia Matsumoto at the Laboratório de Genética e Evolução Molecular de Aves, Universidade de São Paulo, under the supervision of C. Myiaki. J. Mendonça of the Instituto de Pesca and I. Sazima of the Universidade Estadual de Campinas helped to identify photographed fish species seized by beach hunters. K. Müller carefully reviewed the first draft of this manuscript providing comments to improve the flow of the text.

\section{REFERENCES}

BEJDER, L.; FLETCHER, D.; BRÄGER, S. A method for testing association patterns of social animals. Anim. Behav., v. 56, n. 3, p. 719-725, 1998.

BÉRUBÉ, M.; PALSBOLL, P. Identification of sex in cetaceans by multiplexing with three ZFX and ZFY specific primers. Molecular Ecol., v. 5, n. 3, p. 283-287, 1996.

BOWEN, W. D.; READ, A. J.; ESTES, J. A. Feeding ecology. In: HOELZEL, A. R. (Ed.). Marine Mammal Biology: An evolutionary approach. Blackwell Publishing, Malden, MA, USA, p. 217-246, 2002.

BRUFORD M. W.; HANOTTE, O.; BROOKFIELD, J. F. Y.; BURKE, T. Single-locus and multi-locus DNA fingerprinting. In: HOELZEL, A. R. (Ed.). Molecular genetic analyses of populations: A practical approach. New York: Oxford University Press, 1992. p. 255-269, 
BRYANT, L. Report to the Congress on results of feeding wild dolphins: 1989-1994. Silver Spring, MD.: National Marine Fisheries Service, Office of Protected Resources, 1994. 23 p. (Available from NOAA/National Marine Fisheries Service, 1315 East-West Highway, Silver Spring, MD 20910 USA).

CAIRNS, S. J.; SCHWAGER, S. J. A comparison of association indices. Anim. Behav. , v. 35, n. 5, p. 14541469, 1987.

CHILVERS, L.; CORKERON, P. J. Association patterns of bottlenose dolphins (Tursiops aduncus) off Point Lookout, Queensland, Australia. Can. J. Zool., v. 80, n. 6, p. 973-979, 2002

CONNOR, R. C.; SMOLKER, R. A.; RICHARDS, A. F. Two levels of alliance formation among male bottlenose dolphins Tursiops sp. Proc. nat. Acad. Sci., U.S.A, v. 89, n. 3, p. 987-990, 1992.

CONNOR, R. C.; HEITHAUS, M. R.; BERGGREN, P.; MIKSIS, J.L. "Kerplunking": surface fluke-splashes during shallow-water bottom foraging by bottlenose dolphins. Mar. mamm. Sci., v. 16, n. 4, p. 646-653, 2000 .

CONSTANTINE, R. Effects of tourism on marine mammals in New Zealand. Sci. Conserv., v. 106, n. 1, p. 1-60, 1999.

GINSBERG, J. R.; YOUNG, T. P. Measuring association between individuals or groups in behavioural studies. Anim. Behav., v. 44, n. 2, p. 377-379, 1992.

GUINET, C. Intentional stranding apprenticeship and social play in killer whales (Orcinus orca). Can. J. Zool., v. 69, n. 11 , p. $2712-2716,1991$.

HOESE, H. D. Dolphins feeding out of water in a salt marsh. J. Mammal., v. 52, n. 1, p. 222-223, 1971

IFAW. Report of the workshop on the scientific aspects of managing whale watching. Montecastello di Vibio, Italy: IFAW Tethys Research Institute and Europe Conservation, 1995. 40 p. (Available from IFAW, Warren Court, ParkCrowborough, East Sussex, TN6 2GA, United Kingdom).

KARCZMARSKI, L. Group dynamics of humpback dolphins (Sousa chinensis) in the Algoa Bay region, South Africa. J. Zool., v. 249, n. 3, p. 283-293, 1999

KRÜTZEN, M., MANN, J., HEITHAUS, M. R., CONNOR, R. C., BEJDER, L.; SHERWIN, W. B. Cultural transmission of tool use in bottlenose dolphins. Proc. nat.Acad. Sci. U. S A., v. 102, n. 25, p. 8939-8943, 2005.

LOPEZ, J.C.; LOPEZ, D. Killer whales (Orcinus orca) of Patagonia, and their behavior of intentional stranding while hunting nearshore. J. Mammal., v. 66, n. 1, p. 181-183, 1985.

MACIEL, N. A. L. Composição, abundância e distribuição espaço-temporal da ictiofauna do complexo estuarino-lagunar de Iguape-Cananéia, São Paulo, Brasil. Ph. D. Thesis, Instituto Oceanográfico da Universidade de São Paulo, São Paulo, Brazil, 2001. 252 p. (Unpublished)

MANLY, B. F. J. Randomization, Bootstrap and Monte Carlo Methods in Biology. $2^{\text {nd }}$ Edition. London: Chapman and Hall, 1997. 231 p.

MANN, J. Cetacean culture: definitions and evidence. Behavior. Brain Sci., v. 24, n. 2, p. 343, 2001.
MANN, J.; KEMPS, C. The effects of provisioning on maternal care in wild bottlenose dolphins, Shark Bay, Western Australia. In: GALES, N., HINDELL, M.; KIRKWOOD, R. (Ed.). Marine Mammals: Fisheries, Tourism and Management Issues. Collingwood, Victoria, Australia: CSIRO Publishing, 2003. , p. 304317.

MANN, J.; SARGEANT, B. Like mother, like calf: the ontogeny of foraging traditions in wild Indian bottlenose dolphins (Tursiops sp.). In: FRAGAZY, D. M.; PERRY, S. (Ed.). The Biology of traditions, models and evidence. Cambridge, UK.: Cambridge University Press, 2003. p. 236-266.

MENDONÇA, J. T.; KATSURAGAWA, M. Desembarque da pesca costeira em Cananéia, São Paulo, Brasil, durante 1995 e 1996. Nerítica, v. 11, n. 1-2, p. 165-190, 1997.

MONTEIRO-FILHO, E. L. A. Pesca interativa entre o golfinho Sotalia fluviatilis guianensis e a comunidade pesqueira da região de Cananéia. Bolm Inst. de Pesca, S Paulo, v. 22, n. 2, p. 15-23, 1995.

OWEN, E. C. G.; WELLS, R. S.; HOFMAN, S. Ranging and association patterns of paired and unpaired adult male Atlantic bottlenose dolphins, Tursiops truncatus, in Sarasota, Florida, provide no evidence for alternative male strategies. Can. J. Zool., v. 80, n. 12, p. 2072-2089, 2002.

PEDDEMORS, V. M.; THOMPSON, G. Beaching behaviour during shallow water feeding by humpback dolphins Sousa plumbea. Aquatic Mamm., v. 20, n. 2, p. 65-67, 1994

QUINTANA-RIZZO, E.; WELLS, R. S. Resighting and association patterns of bottlenose dolphins (Tursiops truncatus) in the Cedar Keys, Florida: insights into social organization. Can. J. Zool., v. 79, n. 3, p. 477-456, 2001.

RENDELL, L.; WHITEHEAD, H. Culture in whales and dolphins. Behavior. Brain Sci., v. 24, n. 2, p. 309-324, 2001.

SANTOS, M. C. DE O. Uso de área e organização social do boto-tucuxi marinho, Sotalia fluviatilis (Cetacea, Delphinidae), no estuário de Cananéia, SP. Ph. D. Thesis, Instituto de Biociências, Universidade de São Paulo, São Paulo, Brazil, 2004. 265 p.

SANTOS, M. C. DE O., ROSSO, S., SICILIANO, S., ZERBINI, A. N., ZAMPIROLLI, E., VICENTE, A. F.; ALVARENGA, F. Behavioral observations of the marine tucuxi dolphin (Sotalia fluviatilis) in São Paulo estuarine waters, Southeastern Brazil. Aquatic Mamm., v. 26, n. 3, p. 260-267, 2000.

SANTOS, M. C. DE O.; ACUÑA, L. B.; ROSSO, S. Insights on site fidelity and calving intervals of the marine tucuxi dolphin (Sotalia fluviatilis) in southeastern Brazil. Journal of the Marine Biological Association, v. 81, $\mathrm{n}$. 6, p. 1049-1052, 2001.

SANTOS, M. C. DE O.; ROSSO, S.; SANTOS, R. A.; LUCATO, S. H. B.; BASSOI, M. Insights on small cetacean feeding habits in southeastern Brazil. Aquatic Mamm., v. 24, n. 1, p. 38-45, 2002.

SANTOS, M. C. DE O.; ROSSO, S. Ecological aspects of marine tucuxi dolphins (Sotalia guianensis) based on group size and composition in the Cananéia estuary, southeastern Brazil. Latin Amer. J. Aquatic Mamm., v. 6, n. 1, p. 71-82, 2007. 
SANTOS, M. C. DE O.; ROSSO, S. Social organization of marine tucuxi dolphins, Sotalia guianensis, in the Cananéia estuary, southeastern Brazil. J. Mammal., v. 89 , n. 2, p. 347-355, 2008.

SARGEANT, B. L., MANN, J., BERGGREN, P.; KRÜTZEN, M. Specialization and development of beach hunting, a rare foraging behavior, by wild bottlenose dolphins (Tursiops sp.). Can. J. Zool., v. 83, n. 11, p. 1400-1410, 2005.

SCHAEFFER-NOVELLI, Y.; MESQUITA, H. S. L.; CINTRÓN-MOLERO, G. The Cananéia lagoon estuarine system, São Paulo, Brazil. Estuaries v. 13, n. 2, p. $193-$ 203, 1990.

SHANE, S. Behavior and ecology of the bottlenose dolphin at Sanibel Island, Florida. In: LEATHERWOOD, S.; REEVES, R. R. (Ed.). The Bottlenose Dolphin. San Diego, CA.: Academic Press, 1990. p. 245-265.

SLOOTEN, E.; DAWSON, S. M.; WHITEHEAD, W. Associations among photographically identified Hector's dolphins. Can. J. Zool., v. 71, n. 11, p. 2311- 2318, 1993.

SMOLKER, R. A.; RICHARDS, A. F.; CONNOR, R. C.; MANN, J.; BERGGREN, P. Sponge-carrying by Indian Ocean bottlenose dolphins: possible tool use by a delphinid. Ethology v. 103, n. 6, p. 454-465, 1997.

SMOLKER, R. A., RICHARDS, A. F, CONNOR, R. C PEPPER, J. W. Sex differences in patterns of association among Indian Ocean bottlenose dolphins. Behaviour, v. 123, n. 1-2, p. 38-69, 1992.

WELLS, R.S. The role of long-term study in understanding the social structure of a bottlenose dolphin community. In: PRYOR, K.; NORRIS, K. S. (Ed.). Dolphin societies: Discoveries and puzzles. Berkeley, CA: University of California Press, 1991. p. 199-225.

WELLS, R. S.; SCOTT, M. D.; IRVINE, A. B. The social structure of free-ranging bottlenose dolphins. In: GENOWAYS H. H. (Ed.). Current Mammalogy. New York: : Plenium, 1987. p. 247-305.
WHITEHEAD, H. Investigating structure and temporal scale in social organizations using identified individuals. Behav. Ecol., v. 6, p. 199-208, 1995.

WHITEHEAD, H. Analyzing animal social structure. Anim. Behav., v. 53, n. 5, p. 1053-1067, 1997.

WHITEHEAD, H. Testing association patterns of social animals. Anim. Behav., v. 57, n. 6, p. F26-29, 1999.

WHITEHEAD, H.; DUFAULT, S. Techniques for analysing vertebrate social structure using identified individuals: review and recommendations. Adv. Stud. Behav., v. 28, p. 33-74, 1999.

WHITEHEAD, H., RENDELL, L., OSBORNE, R. W.; WÜRSIG, B. Culture and conservation of non-humans with reference to whales and dolphins: review and new directions. Biol. Conserv., v. 120, n. 3, p. 431-441, 2004.

WÜRSIG, B.; WÜRSIG, M. The photographic determination of group size, composition, and stability of coastal porpoises (Tursiops truncatus). Science, v. 198, p. 755756, 1977.

WÜRSIG, B.; JEFFERSON, T. A. Methodology of photoidentification for small cetaceans. In: HAMMOND, P. S., MIZROCH, S. A.; DONOVAN, G. P. (Ed.). Individual Recognition of Cetaceans: Use of Photo-identification and Other Techniques to Estimate Population Parameters. Cambridge, UK.: Reports of the International Whaling Commission, 1990. p. 43-52. Special issue 12 .

(Manuscript received 27 July 2009; revised 14 December 2009; accepted 09 February 2010) 